\title{
The Surface Properties of Neisseria gonorrhoeae: Determinants of Susceptibility to Antibody Complement Killing
}

\author{
By M. E. WARD, P. R. LAMBDEN, J. E. HECKELS AND P. J. WATT \\ Department of Microbiology, Southampton University Medical School, Southampton \\ General Hospital, Southampton SO9 $4 X Y$
}

(Received 13 February 1978; revised 8 May 1978)

\begin{abstract}
Monovalent rabbit antisera were prepared to highly purified gonococcal lipopolysaccharide (LPS), to pili and to two major purified outer envelope proteins. All these antisera were free from significant specific IgM antibody and were standardized to $4 \mu \mathrm{g}$ specific IgG antibody per test, permitting accurate comparisons between the different gonococcal surface antigens as triggers of the complement-dependent bactericidal reaction. LPS was the most effective antigen at inducing a bactericidal response to homologous and heterologous gonococci, followed by the two individual outer envelope proteins. Pili were relatively ineffective. Strain $\mathrm{P} 9$ gonococci grown in vivo or which possessed a 'capsule' in vitro were more resistant to serum killing than the non-capsulated parent strain. One highly susceptible strain, F62, which was killed by complement in the absence of any LPS antibody, was able to directly activate complement by the alternative pathway.
\end{abstract}

\section{INTRODUCTION}

Patients with gonorrhoea produce antibodies which activate complement in a bactericidal reaction against the infecting gonococcus in vitro (Ward et al., 1970; Kasper et al., 1977). Bactericidal antibodies may be important in preventing blood-borne dissemination of gonococci from the mucosal surface because some, but not all, patients with disseminated gonococcal infections have low levels of bactericidal antibodies to their infecting strains (Brookes et al., 1976; Schoolnik et al., 1976) and, as a corollary, gonococcal strains isolated from patients with disseminated infection are commonly resistant to the bactericidal action of normal human sera (Schoolnik et al., 1976). Thus, if the surface antigens concerned in activating antibody-complement killing of gonococci could be identified, these components would be candidates for vaccines giving protection against disseminated disease.

Glynn \& Ward (1970) showed that antibodies reacting with the lipopolysaccharide (LPS) present in the gonococcal outer envelope are bactericidal for gonococci in the presence of complement. Core LPS may act independently of antibody by direct activation of the alternative complement pathway (Götze \& Müller-Eberhard, 1976). Comparatively little attention has been paid to other antigens accessible on the gonococcal outer surface.

Recently some of the major proteins of the gonococcal surface have been isolated in this laboratory (Heckels, 1977; Robertson et al., 1977). Rabbit antisera to these defined antigens have been raised and purified by solid phase immunoadsorption. These antisera, standardized to equivalent concentrations of specific IgG antibody by solid phase radioimmunoassay (Lambden \& Watt, 1978), have been used to probe the importance of the major components of the gonococcal surface in the serum bactericidal reaction 


\section{METHODS}

Bacterial strains. Strains 24585, 24175, 24740, 24764 and 24396 of Neisseria gonorrhoeae were isolated locally and frozen in liquid nitrogen after the minimal number of subcultures necessary to ensure purity (Ward \& Watt, 1971). Strain $\mathrm{P} 9$ had been maintained in this laboratory for some years; strain $\mathrm{P} 9$ (PS) was the parent strain of $\mathrm{P} 9$ which had been subjected to minimal subculture in vitro and has caused a laboratory eye infection; strain P9(GP3) was derived from P9(PS) by three passages through guinea-pig subcutaneous chambers as described by Veale et al. (1975). This guinea-pig strain when grown on the medium of Swanson (1977) was found to be capsulated when stained ty the method of Butt $e$ t al. (1936). Strain FA5 was kindly provided by Dr P. F. Sparling, University of North Carolina, Chapel Hill, U.S.A., strain 201 by Dr K. K. Holmes, University of Washington School of Medicine, Seattle, U.S.A., and strain F62 by Dr D. Kellogg, Jr, Communicable Disease Center, Atlanta, Georgia, U.S.A. All the strains tested were of the pilated colony types 1 or 2 (Kellogg et al., 1963).

Antigens. Strain P9 gonococci were grown in bulk on Difco GC agar base and purified pili were prepared from them as previously described (Robertson et al., 1977). Outer envelope was prepared from the residual depilated organisms by lithium acetate extraction, and the two major outer envelope proteins with molecular weights of 36000 (protein I) and 24500 (protein II) were purified as previously described (Heckels, 1977). Gonococcal LPS was extracted by the phenol/water technique and purified by enzyme treatment as described by Stead et al. (1975).

Antisera. New Zealand White rabbits were injected subcutaneously with $50 \mu \mathrm{g}$ of either purified $\mathrm{P} 9$ pili, LPS, or outer envelope protein in Freund's incomplete adjuvant (Difco) at 0, 2, 4, 6 and 8 weeks. In some cases, the immunization schedule was repeated after a rest period of 6 weeks. Sera showing acceptable levels of antibody activity taken at various times from individual rabbits were pooled and stored at $-70^{\circ} \mathrm{C}$.

Antibody estimations. Purified $\mathbf{9} 9$ pili, LPS, outer envelope, and each of the two outer envelope proteins were coupled to cyanogen bromide activated Sepharose $4 \mathrm{~B}$ (Pharmacia) and used as antigens in a solid phase radioimmunoassay specific for IgG antibodies (Lambden \& Watt, 1978). Pilus antibody was also assessed by dark ground pilus agglutination (Robertson et al., 1977).

Immunoadsorption. Antisera $(5 \mathrm{ml})$ to purified pili and to the individual outer envelope proteins were made monospecific by immunoadsorption on an $18 \times 1.5 \mathrm{~cm}$ column of Sepharose 4B to which strain P9 LPS had been coupled by cyanogen bromide activation. The adsorbed antisera in Dulbecco AB (Oxoid) were concentrated to the original volume by negative pressure dialysis. The column was regenerated without detectable loss of binding capacity using 3 M-sodium trichloroacetate (Porath \& Kristiansen, 1975). The specificity of these antisera was confirmed by solid phase radioimmunoassay to purified pili, LPS, outer envelope and the outer envelope proteins.

Column chromatography. The IgG and IgM fractions from $2 \mathrm{ml}$ of rabbit anti-LPS serum were separated by chromatography on a $1.5 \times 80 \mathrm{~cm}$ column of Ultrogel ACA34 (LKB) in $0 \cdot 1 \mathrm{M}$-Tris buffer $\mathrm{pH} 7 \cdot 5$. The fractions were concentrated to the starting volume of the serum by negative pressure dialysis, then dialysed overnight at $4{ }^{\circ} \mathrm{C}$ against Dulbecco $\mathrm{AB}$ and immediately tested for their bactericidal activity.

Immunofluorescence. Gamma globulin was isolated from $1 \mathrm{ml}$ of sheep anti-rabbit IgM serum (Nordic Immunological, Tillberg, Netherlands) by precipitation with ammonium sulphate. The dialysed globulin was conjugated with fiuorescein isothiocyanate isomer $1(\mathrm{BDH})$ to a fluorescein:protein ratio of 3:6:1. Strain $\mathrm{P} 9$ gonococci were air-dried on to the wells of black Teflon-coated microscope slides (Hendley, Buckhurst Hill, Essex), fixed for $10 \mathrm{~min}$ in acetone at $-20^{\circ} \mathrm{C}$ and dried. The bacteria were incubated with each of the test antisera diluted to contain $4 \mu \mathrm{g}$ specific IgG antibody. The slides were washed with Dulbecco AB and the remaining specifically bound antibody was tested for the presence of rabbit $\mu$ chains using the prepared conjugate. The slides were examined for fluorescence with an Ortholux II microscope equipped with a Ploem I incident light epi-illuminator (Leitz, Wetzlar, W. Germany).

Complement source. Fresh normal human serum from one of the authors (MEW) was used as a source of complement. Natural antibodies cross-reactive with gonococcal core LPS were removed by adsorption of the serum at $4{ }^{\circ} \mathrm{C}$ on a $18 \times 1.5 \mathrm{~cm}$ column of gonococcal LPS coupled to Sepharose 4B equilibrated in Dulbecco $\mathrm{AB}$ (Oxoid). Fractions were pooled, sterilized by filtration, aliquoted and stored at $-70^{\circ} \mathrm{C}$.

Bactericidal test. Eighteen hour cultures of gonococci were suspended in Dulbecco AB to give a turbid suspension. The concentration of gonococci was then adjusted so that a 1 in 10 dilution of the organisms in $1 \mathrm{M}-\mathrm{NaOH}$ had an $A_{260}$ of 0.4 corresponding to a viable count of $10^{8}$ colony forming units (c.f.u.) $\mathrm{ml}^{-1}$. The bacterial suspension(s) were then diluted 10-fold with either fresh normal human serum, or the same serum previously heated at $56^{\circ} \mathrm{C}$ for $30 \mathrm{~min}$ to destroy the complement. The bacterial suspensions in serum $(50 \mu \mathrm{l})$ were then immediately added to the wells of microtitre trays containing either $50 \mu \mathrm{l}$ Dulbecco $\mathrm{AB}$ (controls) or $50 \mu \mathrm{l}$ of the antiserum diluted in Dulbecco AB so as to contain $4 \mu \mathrm{g}$ specific IgG antibody.

For viable count determinations, a Micro-Medic diluter (Micro-Medic Systems, Philadelphia, U.S.A.) 
was used to dilute serially $10 \mu \mathrm{l}$ of sample with $90 \mu \mathrm{l}$ of $1 \%$ proteose peptone no. 3 (Difco), and then $50 \mu \mathrm{l}$ portions were plated on agar and incubated for $48 \mathrm{~h}$ in a moist atmosphere containing $5 \%(\mathrm{v} / \mathrm{v}) \mathrm{CO}_{2}$.

Alternative complement pathway. Activation of complement by the alternative pathway requires $\mathrm{Mg}^{2+}$ and can be distinguished from classical pathway activation which requires $\mathrm{Ca}^{2+}$. The $\mathrm{Ca}^{2+}$ and $\mathrm{Mg}^{2+}$ were removed from the complement by chelation with 10 mM-EDTA. Selective chelation of $\mathrm{Ca}^{2+}$ alone in the presence of $10 \mathrm{~mm}$ added $\mathrm{Mg}^{2+}$ was done with $10 \mathrm{~mm}$-EGTA (Sigma). In both cases, the pH of the mixture was adjusted to 7.4. In bactericidal tests, the toxicity for gonococci of serum containing chelating agent was checked using controls with heat-inactivated complement. Classical complement activation was assessed by titrating two-fold dilutions of the serum in Dulbecco AB against an equal volume of $1.4 \%(\mathrm{v} / \mathrm{v})$ rabbit haemolysin-sensitized sheep red blood cells (r.b.c.) and the alternative pathway was assessed using reduced glutathione-treated human group $\mathrm{O} \mathrm{Rh}^{+}$cells (Stålenheim et al., 1973).

\section{RESULTS}

Normal human sera are bactericidal for many strains of gonococci (Glynn \& Ward, 1970). Using our standard bactericidal test, $10^{4 \cdot 4}$ c.f.u. of an inoculum of $10^{6}$ c.f.u. P9 gonococci survived incubation at $36^{\circ} \mathrm{C}$ for $1 \mathrm{~h}$ in fresh human serum (MEW). The number surviving was increased to $10^{5.7} \mathrm{c}$.f.u. by immunoadsorption of the serum at $4{ }^{\circ} \mathrm{C}$ on a column containing P9 gonococcal LPS. This adsorbed serum was used as a source of complement to study the bactericidal action of $4 \mu \mathrm{g}$ specific antibody directed against the different surface components of the gonococcus.

Despite the use of hyperimmune sera, it was necessary to establish that the sera did not contain IgM antibodies, in particular anti-LPS IgM. When this antiserum was separated by column chromatography, no bactericidal activity was detected in the IgM fraction at a concentration equivalent to undiluted serum (Table 1). In contrast, the IgG fraction diluted to contain $4 \mu \mathrm{g}$ specific antibody against LPS allowed only $10^{3} \mathrm{c}$.f.u. of an inoculum of $10^{4.8}$ c.f.u. to survive for $1 \mathrm{~h}$. As a result of these data and the failure to detect antigonococcal IgM in the sera by immunofluorescence, further work was undertaken with unfractionated sera thus avoiding the possibility of antibody aggregation with loss of activity and non-specific complement fixation.

Antibodies to LPS, the outer envelope proteins I and II, or to pili permitted $10^{2 \cdot 5}, 10^{4 \cdot 7}$, $10^{4 \cdot 9}$ and $10^{5}$ c.f.u., respectively, of an inoculum of $10^{6 \cdot 1}$ c.f.u. P9 gonococci to survive (Table 2). LPS antibody to P9 was clearly the most active in initiating the serum bactericidal reaction, being active against all of the gonococcal strains which were susceptible to serum killing. Antibodies directed against pili and the outer envelope proteins I and II (from strain P9) were also bactericidal for strains 24585,24175 and 24764 although differences exist. However, strain 24740 was sensitive to antibody directed against outer envelope protein I but not to protein II or pili. This suggests that the surface proteins contain common immunodeterminants as well as strain specific components.

Clearly, some gonococcal strains (FA5, 24396) were extremely resistant to the action of complement and the various antibodies whereas other strains (24764, F62) were sensitive to the complement source alone even though it had been freed of natural bactericidal antibody (see Table 2). One possibility is that the extreme sensitivity to complement of strains like F62 might result from the direct activation of the alternative complement pathway by LPS in the outer envelope. To distinguish between the $\mathrm{Ca}^{2+}$-requiring classical and the $\mathrm{Mg}^{2+}$-requiring alternative pathways of complement activation, the $\mathrm{Ca}^{2+}$ or the $\mathrm{Ca}^{2+}$ plus $\mathrm{Mg}^{2+}$ was removed from the complement source by selective chelation with 10 mM-EGTA or EDTA and the resulting serum was tested for its bactericidal activity against F62 (Table 3). In the absence of $\mathrm{Ca}^{2+}$ and $\mathrm{Mg}^{2+}$, both pathways of complement activation were blocked as shown by the failure of the serum to lyse haemolysin-sensitized sheep r.b.c. or to kill F62. When $\mathrm{Ca}^{2+}$ was selectively chelated in the presence of excess $\mathrm{Mg}^{2+}$, classical pathway activity was abolished preventing lysis of the sensitized sheep r.b.c. but alternative pathway activation still occurred as shown by lysis of reduced glutathione-treated human r.b.c. 
Table 1. The role of $\operatorname{Ig} G$ and $\operatorname{Ig} M$ antibodies in the complement-dependent bactericidal action of lipopolysaccharide (LPS) antibodies for $N$. gonorrhoeae strain $\mathrm{P} 9$

Reaction components

Fresh adsorbed serum (MEW) as

complement source (C)

C+ whole anti-LPS serum

(4 $\mu \mathrm{g}$ specific IgG antibody)

$\mathrm{C}+$ anti-LPS serum IgG fraction

(4 $\mu \mathrm{g}$ specific antibody)

$\mathrm{C}+$ whole undiluted anti-LPS serum

$\mathrm{C}+$ undiluted IgM fraction of anti-LPS serum
Number $\left(\log _{10}\right)$ of c.f.u. surviving*

4.5
3.2
3.0
0.8
4.5

* Mixtures were incubated at $36^{\circ} \mathrm{C}$ for $1 \mathrm{~h}$. The inoculum was $10^{4 \cdot 8} \mathrm{c}$.f.u. $\mathrm{P} 9$ colony type 1 gonococci. The numbers of gonococci given were corrected for antibody-mediated bacterial agglutination using a test control containing antibody but no complement.

Table 2. Comparison of the ability of $4 \mu \mathrm{g}$ specific IgG antibody to strain $\mathrm{P} 9$ gonococcal pili, LPS or outer envelope proteins to induce complement-dependent bactericidal activity against nine strains of $N$. gonorrhoeae

Number $\left(\log _{10}\right)$ of c.f.u. surviving $\dagger$

Strain of $N$. gonorrhoeae (colony type 1):

Antiserum

in test mixture*

None

LPS

Protein I

Protein II

Pili

Inoculum c.f.u.

$\begin{array}{cc}\text { P9 } & 24585 \\ 5 \cdot 8 & 5 \cdot 8 \\ 2 \cdot 5 & 4 \cdot 3 \\ 4 \cdot 7 & 4 \cdot 4 \\ 4 \cdot 9 & 5 \cdot 1 \\ 5 \cdot 0 & 5 \cdot 2 \\ 6 \cdot 1 & 6 \cdot 1\end{array}$

24175
$6 \cdot 8$
$1 \cdot 7$
$1 \cdot 7$
$5 \cdot 9$
$6 \cdot 0$
$6 \cdot 5$

$\begin{array}{cc}24740 & 201 \\ 5 \cdot 9 & 5 \cdot 2 \\ 3 \cdot 9 & 3 \cdot 2 \\ 4 \cdot 9 & 5 \cdot 5 \\ 6 \cdot 0 & 4 \cdot 9 \\ 5 \cdot 7 & 5 \cdot 6 \\ 6 \cdot 0 & 6 \cdot 0\end{array}$

24764
4.4
2.5
3.4
3.9
4.8

$\begin{array}{ccc}\text { FA5 } & 24396 & \text { F62 } \\ 5.6 & 6.8 & <2.0 \\ 5.3 & 6.8 & <2.0 \\ 5.5 & 6.8 & <2.0 \\ 5.5 & 6.8 & <2.0 \\ 5.5 & 6.8 & <2.0 \\ 5.7 & 6.8 & 6.0\end{array}$

* Bacterial suspensions in adsorbed fresh human serum (MEW) were added to antiserum to components of strain P9 containing $4 \mu \mathrm{g}$ specific (IgG) antibody, standardized by solid phase radioimmunoassay with ${ }^{3} \mathrm{H}$-labelled protein $\mathrm{A}$.

$\dagger$ Mixtures were incubated at $36^{\circ} \mathrm{C}$ for $1 \mathrm{~h}$. Counts were corrected as in Table 1 . In controls lacking complement, viable counts at $1 \mathrm{~h}$ were always within $\pm 10^{0 \cdot 3}$ c.f.u. of the inoculum at zero time.

Table 3. The role of classical and alternative pathway complement activation, as distinguished by selective chelation of $\mathrm{Ca}^{2+}$ or $\mathrm{Ca}^{2+}$ plus $\mathrm{Mg}^{2+}$ ions, in the bactericidal activity of fresh human serum for $\mathrm{F} 62$ gonococci

Dilution of serum after incubation for $1 \mathrm{~h}$ at $36{ }^{\circ} \mathrm{C}$ lysing an equal volume of:

\footnotetext{
Modification to fresh serum (MEW)

None

Heated at $56^{\circ} \mathrm{C}, 30 \mathrm{~min}$

$\mathrm{Ca}^{2+}+\mathrm{Mg}^{2+}$ removed $\dagger$

$\mathrm{Ca}^{2+}$ removed, excess $\mathrm{Mg}^{2+} \ddagger$

Number $\left(\log _{10}\right)$ of c.f.u. surviving* $2 \cdot 1$ $6 \cdot 1$ $5 \cdot 8$ 3.9

(classical pathway) (alternative pathway)§

$\begin{array}{ll}1: 40 & \text { NT } \\ \text { None } & \text { None } \\ \text { None } & \text { None } \\ \text { None } & 1: 10\end{array}$

* Mixtures were incubated at $36^{\circ} \mathrm{C}$ for 1 h. The inoculum was $10^{6 \cdot 1}$ c.f.u. F62 colony type 1 . Counts were corrected for appropriate controls.

$\dagger$ Removed by chelation with 10 mM-EDTA; pH maintained at $7 \cdot 4$.

$\$ 10 \mathrm{mM}-\mathrm{Mg}^{2+}$ added; $\mathrm{Ca}^{2+}$ removed by selective chelation with $10 \mathrm{mM}-\mathrm{EGTA}$; pH maintained at 7.4.

$\$$ Human group $\mathrm{O} \mathrm{Rh}^{+}(\mathrm{MEW})$ r.b.c. treated at $37^{\circ} \mathrm{C}$ for $1 \mathrm{~h}$ with $0.15 \mathrm{M}$-reduced glutathione (GSH) followed by extensive washing in Dulbecco AB. Treated cells were used to measure antibody-independent lysis due to the alternative pathway. NT, Not tested.
}

$\overbrace{1.4 \%(\mathrm{v} / \mathrm{v}) \text { haemolysin- }}^{1.4 \%(\mathrm{v} / \mathrm{v}) \mathrm{GSH}-}$


Table 4. Susceptibility of $\mathrm{P9}$ gonococci grown in vivo and of 'capsulated' $\mathrm{P} 9$ gonococci to killing by antibody and complement

\begin{tabular}{|c|c|c|c|}
\hline \multirow[b]{2}{*}{$\begin{array}{l}\text { Antiserum in } \\
\text { test mixture* }\end{array}$} & \multicolumn{3}{|c|}{$\begin{array}{c}\text { Number }\left(\log _{10}\right) \text { of c.f.u. surviving after incubation } \\
\text { of mixtures at } 36^{\circ} \mathrm{C} \text { for } 1 \mathrm{~h}\end{array}$} \\
\hline & $\begin{array}{l}\text { Parent strain } \\
\text { [P9(PS)] }\end{array}$ & $\begin{array}{l}\mathrm{P} 9(\mathrm{PS}) \text { grown } \\
\text { in vivo }+[\mathrm{P} 9(\mathrm{GP} 3)]\end{array}$ & $\begin{array}{l}\text { P9(GP3) after one } \\
\text { subculture in vitro } \\
\text { ('capsulated') }\end{array}$ \\
\hline $\begin{array}{l}\text { None } \\
\text { LPS } \\
\text { Protein I } \\
\text { Protein II } \\
\text { Pili }\end{array}$ & $\begin{array}{l}4 \cdot 1 \\
2 \cdot 2 \\
3 \cdot 9 \\
3 \cdot 9 \\
3 \cdot 7\end{array}$ & $\begin{array}{l}4 \cdot 5 \\
3 \cdot 4 \\
4 \cdot 1 \\
4 \cdot 5 \\
4 \cdot 6\end{array}$ & $\begin{array}{l}4 \cdot 4 \\
4 \cdot 1 \\
4 \cdot 1 \\
4 \cdot 2 \\
4 \cdot 5\end{array}$ \\
\hline Inoculum c.f.u. & $4 \cdot 4$ & 4.9 & $4 \cdot 6$ \\
\hline
\end{tabular}

\footnotetext{
* Bacterial suspensions in adsorbed fresh human serum (MEW) were added to antiserum to components of strain P9 containing $4 \mu \mathrm{g}$ specific (IgG) antibody.

† Organisms grown in guinea-pig chambers were sedimented and the pellet was gently rinsed three times with Dulbecco AB.

$\ddagger$ Strain P9(GP3), grown in guinea-pig chambers, was subcultured once for $18 \mathrm{~h}$ on to the medium of Swanson (1977).
}

(Stålenheim et al., 1973). Under these conditions only $10^{3 \cdot 9} \mathrm{c}$. f.u. of an inoculum of $10^{6 \cdot 1}$ c.f.u. F62 organisms survived (Table 3).

Gonococci which have grown in vivo in the natural host are more resistant to the bactericidal action of antibody and complement than the same organism in artificial culture (Ward et al., 1970). This resistance appears to be a phenotypic response to the altered growth conditions in vivo and may reflect the elaboration of different surface antigens such as the 'capsule-like' structure which has recently been reported (Hendley et al., 1977; James \& Swanson, 1977). Therefore the susceptibility to serum killing of the parent strain of $\mathrm{P} 9$, i.e. $\mathrm{P} 9$ (Ps), was compared with that of $\mathrm{P9}$ which had been maintained in vivo in guineapig subcutaneous chambers [P9(GP3)]. The results confirmed that P9(GP3), when recovered direct from the chamber fluid, was more resistant than P9(PS) to killing by LPS antibody and complement (Table 4). Gonococci grown in guinea-pig chambers possess capsules (Hormaeche et al., 1978) which might explain this resistance to serum killing. These capsules could be maintained in vitro by growth on laboratory medium. The capsulated organism was comparable to the organism grown in vivo in its resistance to serum killing and was more resistant than the non-capsulated P9(PS) (Table 4). Little significant difference was found in the susceptibility of P9(PS) and extensively subcultured $\mathrm{P} 9$ to serum killing (Tables 2 and 4) despite known differences in their outer envelope structure (Heckels \& Everson, 1978).

\section{DISCUSSION}

In this study the role of antibodies prepared to purified gonococcal surface components was investigated in preference to inhibition studies with the antigens themselves. This approach was chosen because of the difficulty of excluding the presence of small but immunologically significant amounts of contaminating antigens in the surface components.

Following immunoadsorption, the antisera were monospecific as shown by the lack of antibody to other surface components on radioimmunoassay. Thus the results establish that antibody to the individual outer envelope proteins, and particularly to LPS, are bactericidal for the homologous and some heterologous gonococci. By contrast, pili were only capable of inducing a weak bactericidal response, perhaps because most antibody 
binding and complement activation occurs at sites too remote from the target cytoplasmic membrane to be effective in serum killing.

The results show that at the standardized level of $4 \mu \mathrm{g}$ specific (IgG) antibody, LPS antibody was clearly the most effective at inducing serum killing. This was not due to the presence of specific IgM antibodies, nor was there evidence in any of the antisera of a prozone effect due to blocking antibodies such as non-complement fixing IgA antibodies. The importance of LPS antibody in the bactericidal action of human sera from normal or gonococcal infected subjects (Tramont et al., 1974; Rice \& Kasper, 1977) or in rabbit antisera to whole gonococci (Glynn \& Ward, 1970) is firmly established. LPS tends to induce an IgM response (Cohen, 1967). These antibodies on a mole for mole basis are more actively bactericidal than IgG. Thus LPS may be the critical antigen for the bactericidal reaction in patients with gonorrhoea.

One explanation for the efficiency of LPS antibodies is that a larger area of gonococcal surface is occupied by LPS than by the outer envelope proteins. Thus calculations based on the mass of LPS in the lithium acetate extracted outer envelope of $P 9$ suggest the ratio of LPS : outer envelope protein to be at least $2: 1$, although not all of this may be surface antigen. In gonococci, LPS is thought to form a continuous back-bone layer in which the protein molecules are embedded (Novotny et al., 1977). A greater availability of LPS would increase the likelihood of two molecules of $\operatorname{lgG}$ antibody binding in sufficiently close proximity to activate complement. An alternative suggestion is that the LPS antigen fixes complement at a site (e.g. the core region) which is closer to the vulnerable lipid of the membrane.

Gonococcal LPS from different strains have similar core components (Perry et al., 1975; Stead et al., 1975) although there may be differences in the linkages. The $O$ antigen chains (Perry et al., 1975) are produced inconsistently in response to as yet undefined growth conditions. The failure of antibody to kill strains such as FA5 and 24396 must be due to other factors such as the presence of blocking antigens (Glynn \& Ward, 1970) or of permeability barriers to the later activated complement components. Strains FA5, F62 and 201 differ from P9 and other English strains tested in that they lack protein II (Heckels, 1977). Strain P9(PS) differs from the extensively subcultured P9 in possessing lower amounts of protein II and by the retention of a third major protein (protein III, molecular weight 60000 ) in lithium acetate extracted outer envelope prepared from it (Heckels, 1978). Thus there are important differences in the organization of the surface layers in these strains, but any obvious correlation between them and the susceptibility of these strains to serum killing was not forthcoming (Tables 2 and 4).

Gonococci grown in vivo in patients with gonorrhoea (Ward et al., 1970) or in guinea-pig subcutaneous chambers (Penn et al., 1977) were resistant to serum killing but rapidly became sensitive on subculture in vitro. The possibility that this in vivo resistance is due to adsorbed host material blocking antibody binding sites cannot be totally excluded. Nevertheless, it seems likely that the phenotypic effect of growth in vivo induces variations in surface structure, such as the production of O chains on the LPS, which may increase resistance to serum killing. Gonococci freshly isolated from guinea-pig subcutaneous chambers possess an extra 'capsular' surface layer which can be visualized by electron microscopy after fixation in the presence of lanthanum (Hormaeche et al., 1978) and which is morphologically similar to the 'capsules' reported by other workers on gonococci grown under special conditions in vitro (Hendley et al., 1977; James \& Swanson, 1977). The data presented in Table 4 confirm that gonococci grown in guinea-pig chambers are resistant to serum killing and are capsulated on subculture. Capsulated gonococci grown in vitro were less susceptible to killing by LPS antibody and complement than ordinary subcultured P9 or P9(PS). Further work is needed to establish the mechanism of this resistance.

Some strains, notably F62, were highly susceptible to serum killing by complement alone. In the absence of LPS antibody in the complement source, it seemed likely that these strains 
were directly activating complement by the alternative pathway (Götze \& Müller-Eberhard, 1976), perhaps because the 'rough' LPS core is relatively exposed. This theory was supported by the finding reported here that significant numbers of gonococci were killed by complement in the absence of $\mathrm{Ca}^{2+}$ provided that $\mathrm{Mg}^{2+}$ was present; under these conditions only the alternative pathway operates. Activation of complement through the alternative pathway by $\mathrm{F} 62$ gonococci was confirmed by the lysis of reduced glutathione-treated human r.b.c. (Stålenheim et al., 1973). Interactions of gonococci with the alternative complement pathway have largely been ignored although Scherer \& Braun-Falco (1976) using immunofluorescence have suggested that the allergic vasculitis in the skin lesions of benign gonococcal sepsis results from direct activation of the alternative complement pathway by gonococci. This pathway might also be involved in the generation of the acute inflammatory response so characteristic of gonorrhoea.

As patients with disseminated gonococcal infection do not produce bactericidal antibodies to the infecting gonococcus, the serum killing reaction may be protective in uncomplicated gonorrhoea. The susceptibility of patients with complement deficiency to disseminated forms of gonococcal infection (Brooks et al., 1976) can also be explained by the failure to mount an effective bactericidal response. Moreover, in both the guinea-pig and chimpanzee models of gonococcal infection, protective immunity correlates best with the levels of bactericidal antibody (Wong et al., 1976; Arko et al., 1976). LPS antibodies are almost certainly involved in these protective responses. However the results reported here show that protein antigens are also involved in serum killing and the cross-reactivity of the exposed immunodeterminants on these proteins and their protective role needs to be evaluated. The newly described 'capsular' layer on gonococci must be isolated and antibodies raised against it to determine the number of immunotypes and whether antibodies to it are protective. Hopefully this molecular approach may eventually lead to the development of a vaccine.

We are grateful to the Medical Research Council for a programme grant in support of this work.

\section{REFERENCES}

Arko, R. J., DUNCaN, W. P., Brown, W. J., Peacock, W. L. \& Tomizawa, T. (1976). Immunity in infection with Neisseria gonorrhoeae: duration and serological response in the chimpanzee. Journal of Infectious Diseases 133, 441-447.

Brooks, G. F., Israel, K. S. \& Peterson, B. H. (1976). Bactericidal and opsonic activity against Neisseria gonorrhoeae in sera from patients with disseminated gonococcal infection. Journal of Infectious Diseases 134, 450-462.

BuTt, E. M., BoNyNGE, C. W. \& Joyce, R. L. (1936). The demonstration of capsules about haemolytic streptococci with India ink and azo-blue. Journal of Infectious Diseases 58, 5-11.

CoHEN, I. R. (1967). Natural and immune human antibodies reactive with antigens of virulent Neisseria gonorrhoeae: Immunoglobulins G, M and A. Journal of Bacteriology 94, 141-148.

GlynN, A. A. \& WARD, M. E. (1970). Nature and heterogeneity of the antigens of Neisseria gonorrhoeae involved in the serum bactericidal reaction. Infection and Immunity 2, 162-168.

GöTzE, O. \& MÜller-EBeRHARD, H. J. (1976). The alternative pathway of complement activation. Advances in Immunology 24, 1-35.

HeCkels, J. E. (1977). The surface properties of Neisseria gonorrhoeae: isolation of the major components of the outer membrane. Journal of General Microbiology 99, 333-341.

HeCKELS, J. E. (1978). The surface properties of Neisseria gonorrhoeae: topographical distribution of the outer membrane protein antigens. Journal of General Microbiology 108, 213-219.

HeCKels, J. E. \& Everson, J. S. (1978). The isolation of a new outer membrane protein from the parent strain of Neisseria gonorrhoeae $\mathrm{P} 9$. Journal of General Microbiology 106, 179-182.

Hendley, J. O., Powell, K. R., Rodewald, R., HolzGReFe, H. H. \& LYLES, R. (1977). Demonstration of a capsule on Neisseria gonorrhoeae. New England Journal of Medicine 296, 608-612.

Hormaeche, R. D., Thornley, M. J. \& Glauert, A. M. (1978). Demonstration by light and electron microscopy of capsules on gonococci recently grown in vivo. Journal of General Microbiology 106, 81-91.

JAMES, J. F. \& Swanson, J. (1977). The capsule of the gonococcus. Journal of Experimental Medicine 145, 1082-1086.

KASPER, D. L., Rice, P. A. \& MCCoRmaCK, W. M. (1977). Bactericidal antibody in genital infection due to Neisseria gonorrhoeae. Journal of Infectious Diseases 135, 243-251.

Kellogg, D. S., Peacock, W. L., Deacon, W. E., 
Brown, L. \& Pirkle, C.I. (1963). Neisseria gonorrhoeae. I. Virulence genetically linked to clonal variation. Journal of Bacteriology 85, 1274 1279.

LAMBden, P. R. \& WATT, P. J. (1978). A solid phase radio-immunoassay on hydrophobic membrane filters: detection of antibodies to gonococcal surface antigens. Journal of Immunological Methods 20, 277-286.

Novotny, P., Short, J. A., Hughes, M., Miler, J. J., Syrett, C., Turner, W. H., Harris, J. R. W. \& MaclenNaN, I. P. B. (1977). Studies on the mechanism of pathogenicity of Neisseria gonorrhoeae. Journal of Medical Microbiology 10, 347365.

PenN, C. W., Veale, D. R. \& SMith, H. (1977). Selection from gonococci grown in vitro of a colony type with some virulence properties of organisms adapted in vivo. Journal of General Microbiology 100, 147-158.

Perry, M. B., Daoust, V., Diena, B. B., Ashton, F. E. \& Wallace, R. (1975). The lipopclysaccharides of Neisseria gonorrhoeae colony types 1 and 4. Canadian Journal of Biochemistry 53, 623629.

Porath, J. \& Kristiansen, T. (1975). Biospecific affinity chromatography and related methods. In The Proteins, vol. 1, 3rd edn, pp. 95-178. Edited by H. Neurath, R. L. Hill \& C. L. Boeder. New York: Academic Press.

RICE, P. A. \& KASPER, D. L. (1977). Characterization of gonococcal antigens responsible for induction of bactericidal antibody in disseminated infection. Journal of Clinical Investigation 60 , 1149-1158.

Robertson, J. N., Vincent, P. \& WARD, M. E. (1977). The preparation and properties of gonococcal pili. Journal of General Microbiology 102, 169177.

SCHERER, R. \& Braun-Falco, O. (1976). Alternative pathway complement activation: a possible mechanism inducing skin lesions in benign gonococcal sepsis. British Journal of Dermatology 95, 303-309.
Schoolnik, G. K., Buchanan, T. M. \& Holmes, K. K. (1976). Gonococci causing disseminated gonococcal infections are resistant to the bactericidal action of normal human sera. Journal of Clinical Investigation 58, 1163-1173.

StÅlenheim, G., Götze, O., COOPer, N. R., SJÖQuist, J. \& MülleR-EBERHARD, H. J. (1973). Consumption of human complement components by complexes of IgG with protein A of Staphylococcus aureus. Immunochemistry 10, 501-507.

Stead, A., Main, J. S., Ward, M. E. \& Watt, P. J. (1975). Studies on lipopolysaccharides isolated from strains of Neisseria gonorrhoeae. Journal of General Microbiology 88, 123-131.

Swanson, J. (1977). Surface components associated with gonococcal-cell interactions. In The Gonococcus, pp. 369-402. Edited by R. B. Roberts. New York: John Wiley.

Tramont, E. C., Sadoff, J. C. \& Artenstein, M. S. (1974). Cross reactivity of Neisseria gonorrhoeae and Neisseria meningitidis and the nature of antigens involved in the bactericidal reaction. Journal of Infectious Diseases 130, 240-247.

Veale, D. R., Smith, H., WitT, K. \& Marshall, R. B. (1975). Differential ability of colonial types of Neisseria gonorrhoeae to produce infection and an inflammatory response in subcutaneous perforated plastic chambers in guinea pigs and rabbits. Journal of Medical Microbiology 8, 325335.

WARD, M. E. \& WATT, P. J. (1971). The preservation of gonococci in liquid nitrogen. Journal of Clinical Pathology 24, 122-123.

WARD, M. E., WATt, P. J. \& GlynN, A. A. (1970). Gonococci in urethral exudates possess a virulence factor lost on subculture. Nature, London 227, 382384.

Wong, K. H., Arko, R. J., Logan, L. C. \& BulLARD, J. C. (1976). Immunological and serological diversity of Neisseria gonorrhoeae: gonococcal serotypes and their relationship with immunotypes. Infection and Immunity 14, 1297-1301. 